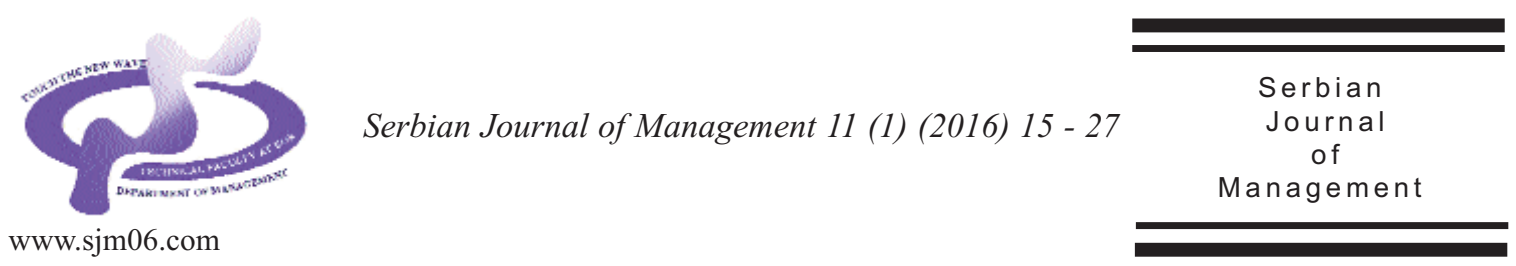

\title{
AN INTEGRATED FUZZY AHP AND TOPSIS MODEL FOR SUPPLIER EVALUATION
}

\author{
Željko Stevića $^{\mathbf{a}^{*}}$, Ilija Tanackov ${ }^{b}$, Marko Vasiljevića ${ }^{\mathbf{a}}$, Boris Novarlićc \\ and Gordan Stojićb

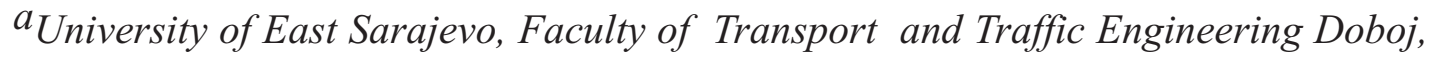 \\ Vojvode Mišića 52, 74000 Doboj, Bosnia and Herzegovina

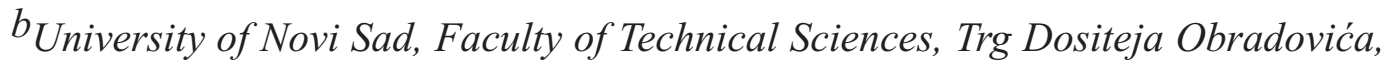 \\ 21000 Novi Sad, Serbia \\ ${ }^{c}$ KP "Progres" ad, Doboj, Karađorđeva 10, 74000 Doboj, Bosnia and Herzegovina
}

(Received 8 February 2016; accepted 5 April 2016)

\begin{abstract}
In today's modern supply chains, the adequate suppliers' choice has strategic meaning for entire companies' business. The aim of this paper is to evaluate different suppliers using the integrated model that recognizes a combination of fuzzy AHP (Analytical Hierarchy Process) and the TOPSIS method. Based on six criteria, the expert team was formed to compare them, so determination of their significance is being done with fuzzy AHP method. Expert team also compares suppliers according to each criteria and on the base of triangular fuzzy numbers. Based on their inputs, TOPSIS method is used to estimate potential solutions. Suggested model accomplishes certain advantages in comparison with previously used traditional models which were used to make decisions about evaluation and choice of supplier.
\end{abstract}

Keywords: Fuzzy AHP, TOPSIS, Supplier evaluation, Multi-criteria decision making

\section{INTRODUCTION}

In day-to-day business, making decisions which will, on one side lessen the expenses, and on the other side fulfill user's needs, certainly represents a challenge.
Accordingly, decision makers are bearing great responsibility when modeling supply chain which includes the above mentioned. Their task can be manifested through accomplishments of logistics triangle, which is made of expenses, time and quality.

\footnotetext{
*Corresponding author: zeljkostevic88@yahoo.com DOI:10.5937/sjm11-10452
} 
Satisfying these needs that are placed in front of decision makers requires systematic approach which is mirrored in expenses' reduce in every sub-system of logistics, shortening of time needed for certain operations accomplishments, as well as entire process needed for realization of goods delivery. Besides, company must strive to enlarge the quality of product itself, so the end user is satisfied with provides services, what would make him a loyal user. Due to above mentioned, it is necessary, during the first phase of logistics, ie. purchasing logistics, to commit good evaluation and choice of supplier, what can largely influence the forming of product's final price and in that way accomplish significant effect in complete supply chain. It is possible to accomplish the above mentioned if evaluation is being done based on multi-criteria decision making that includes large number of criteria and expert's estimation of their relative significance, since one of the most important characteristics of multi-criteria decision making is that different criteria can not have equal importance (Stević et. al., 2015a).

Multi-criteria analysis is rapidly expanding, especially during the past several years, and therefore, big number of problems is being solved nowadays using methods from that area. It is being used for solving problems of diferent nature, it is also greatly accepted and used in the area of management and logistics, where certain decisions are being made exactly on the base of multicriteria methods. There is a great number of methods belonging to the area of multicriteria decision making, and the most often used, at least when dealing with supplier choice, are the AHP and TOPSIS methods, that are used in this paper for evaluation of supplier.
The AHP method was previously used to address the problem of supplier selection, whether in the conventional form or in a combination with fuzzy logic, for example in (Nydick \& Hill, 1992; Chen et. al., 2006; Stević et al., 2015b), supplier selection in industry (Barbarosoglu \& Yazgac, 1997), supplier selection for the textile company (Ertugrul \& Karakasoglu, 2006), the area of production (Chan \& Kumar, 2007), the area of production TFT-LCD (Lee, 2009), electronic procurement (Benyoucef \& Canbolat, 2007), in washing machine company (Kilincci \& Onal, 2011), in a gear motor company (Ayhan, 2013), suppliers for white good manufacturers (Kahraman et. al., 2003), while Ho, along with co-authors in (Ho et. al. 2010) conducted a literature review of the application of multi-criteria analysis in the mentioned field. There are other areas where this method is applied, for example catering services evaluating (Kahraman et. al., 2004), evaluating and selecting a vendor in a supply chain model (Haq \& Kannan, 2006), evaluating and selection of computers (Srichetta \& Thurachon, 2012), evaluation of impact of safety training programme (Raja Prasad \& Chalapathi Venkata, 2013).

\section{RESEARCH}

AHP is often used in combination with other methods, as evidenced by (Stević et al., 2015c) where the authors are using AHP in their work to assess the difficulty of criteria, and Topsis method for obtaining the final ranking of alternatives or combination fuzzy AHP and Topsis method (Ballı \& Korukoğlu, 2009; Mahmoodzadeh et al., 2007), combination fuzzy AHP and fuzzy Topsis (Sun, 2010; Zeydan et al., 2011; Shukla et 
al., 2014; Bronja \& Bronja, 2015).

For the purpose of suppliers' evaluation, this paper uses the combination of methods of mulit-criteria analysis. Fuzzy analiticalhierarchy proccess (FAHP) had been used for determination of significance of criteria, which compares criteria based on fuzzy scales for comparison, while Topsis method was used for alternatives' ranking.

\subsection{Conventional AHP method}

Analytic hierarchy process is created Thomas Saaty (Saaty, 1980) and according to him (Saaty, 2008) AHP is a measurement theory which is dealing with pairs comparing and which relies on expert opinion in order to perform the priority scale. With AHP according (Saaty, 1988), it is possible to identify the relevant facts and connections existing between them. Parts of AHP method are problem decomposition, where the goal is located at the top, followed by criteria and sub-criteria, and at the end of the hierarchy are potential solutions, explained in more details by (Saaty, 1990).

In (Saaty, 1986) is defined the axioms which the AHP is based on: the reciprocity axiom. If the element $\mathrm{A}$ is $\mathrm{n}$ times more significant than the element $\mathrm{B}$, then element $\mathrm{B}$ is $1 / \mathrm{n}$ times more significant than the element A; Homogeneity axiom. The comparison makes sense only if the elements are comparable, e.g. weight of a mosquito and an elephant may not be compared; Dependency axiom. The comparison is granted among a group of elements of one level in relation to an element of a higher level, i.e. comparisons at a lower level depend on the elements of a higher level; Expectation axiom. Any change in the structure of the hierarchy requires recomputation of priorities in the new hierarchy. More details on the analytic hierarchy process are found in the book of (Saaty \& Vargas, 2012).

Some of the key and basic steps in the AHP methodology according to (Vaidya \& Kumar, 2006) are as follows: to define the problem, expand the problem taking into account all the actors, the objective and the outcome, identification of criteria that influence the outcome, to structure the problem previously explained hierarchy, to compare each element among them at the appropriate level, where the total of $\mathrm{nx}(\mathrm{n}$ 1)/2 comparisons is necessary, to calculate the maximum value of own vector, the consistency index and the degree of consistency.

AHP in a certain way solves the problem of subjective influence of the decision-maker by measuring the level of consistency (CR) and notifies the decision maker thereof. If the level of consistency is in the range up to 0.10 , the results are considered valid. Some authors take even greater degree of consistency as valid, which of course is not recommendable. This coefficient is recommended depending on the size of the matrix, so we may find in the papers of (Anagnostopoulos et al., 2007) that the maximum allowed level of consistency for the matrices $3 \times 3$ is $0.05,0.08$ for matrices $4 \times 4$ and 0.1 for the larger matrices. If the calculated CR is not of the satisfactory value, it is necessary to repeat the comparison to have it within the target range (Saaty, 2003).

\subsection{Chang's extent analysis}

When it comes to decision making using fuzzy AHP method, various approaches were developed as expanded fuzzy AHP method based on triangular fuzzy numbers (Chang, 1996; Zhu et al., 1999), fuzzy preference 
programming developed by (Mikhailov, 2003), logarithmic fuzzy preference programming originated from the above mentioned access by its expanding, which was developed by (Wang \& Chin, 2011).

The theory of fuzzy sets was first introduced by (Zadeh, 1965), whose application enables decision makers to effectively deal with the uncertainties. Fuzzy sets used generally triangular, trapezoidal and Gaussian fuzzy numbers, which convert uncertain fuzzy numbers numbers. Fuzzy set is according to (Xu \& Liao, 2014) a class of objects characterized by function of belonging, in which each object is getting a grade of belonging to the interval $(0,1)$. Triangular fuzzy numbers, which were used in this work are marked as (lij, mij, uij). The parameters (lij, mij, uij) are the smallest possible value, the most promising value and highest possible value that describes a fuzzy event, respectively.

Chang's extended analysis, despite the papers of (Wang et al., 2008; Fazlollahtabar et al., 2010) who criticize this method, is widely used for decision making in various fields.

According to (Xu \& Liao, 2014), one of the disadvantages of the expanded AHP analysis is considered to be not taking into account the consistency degree, i.e. failure to calculate its value. However, it can be calculated by taking the crisp value.

Lets assume that $\mathrm{X}=\left\{\mathrm{x}_{1}, \mathrm{x}_{2}, \ldots, \mathrm{x}_{\mathrm{n}}\right\}$ is number of objects, and $U=\left\{\mathrm{u}_{1}, \mathrm{u}_{2}, \ldots, \mathrm{u}_{\mathrm{m}}\right\}$ is number of aims.

According to the methodology of extended analysis set up by Chang, for each object an extended goal analysisis is made. Values of the extended analysis " $m$ " for each object can be represented as follows:
$M_{g i,}^{1} M_{g i,}^{2} M_{g i,}^{m} i=1,2, \ldots n .$,

where $M_{g}^{j}, j=1,2, \ldots m$., are fuzzy triangular numbers. Chang's expanded analysis includes following steps:

Step 1: Values of fuzzy extension for the i-th object are given by the equation:

$S_{i}=\sum_{j=1}^{n} M_{g i}^{j} \times\left[\sum_{\mathrm{i}=1}^{\mathrm{n}} \sum_{\mathrm{j}=1}^{\mathrm{m}} M_{g i}^{j}\right]^{-1}$

In order to obtain expression

$\left[\sum_{\mathrm{i}=1}^{\mathrm{n}} \sum_{\mathrm{j}=1}^{\mathrm{m}} M_{g i}^{j}\right]^{-1}$

it is necessary to perform additional fuzzy operations with " $\mathrm{m}$ " values of the extended analysis, which is represented by the following expressions:

$\sum_{j=1}^{n} M_{g i}^{j}=\left(\sum_{j=1}^{m} l_{j}, \sum_{j=1}^{m} m_{j}, \sum_{j=1}^{m} u_{j}\right)$

$\sum_{i=1}^{n} \sum_{j=1}^{n} M_{g i}^{j}=\left(\sum_{i=1}^{n} l_{i}, \sum_{i=1}^{n} m_{i}, \sum_{i=1}^{n} u_{i}\right)$

Then it is necessary to calculate the inverse vector:

$\left[\sum_{\mathrm{i}=1}^{\mathrm{n}} \sum_{\mathrm{j}=1}^{\mathrm{m}} M_{g i}^{j}\right]^{-1}\left[\frac{1}{\sum_{i=1}^{n} u_{i}}, \frac{1}{\sum_{i=1}^{n} m_{i}}, \frac{1}{\sum_{i=1}^{n} l_{i}}\right]$

Step 2: Possibility degree $\mathrm{Sb}>\mathrm{Sa}$ is defined:

$V\left(S_{b} \geq S_{a}\right)=\left\{\begin{array}{cl}1, & \text { if } m_{b} \geq m_{a} \\ 0, & \text { if } l_{a} \geq u_{b} \\ \frac{l_{a}-u_{b}}{\left(m_{b}-u_{b}\right)-\left(m_{a}-l_{a}\right)}, & \text { therwise }\end{array}\right.$

where „d“ ordinate of a largest cross-section in point $\mathrm{D}$ between $\mu \mathrm{Sa}$ andi $\mu \mathrm{Sb}$ as shown in figure 1 .

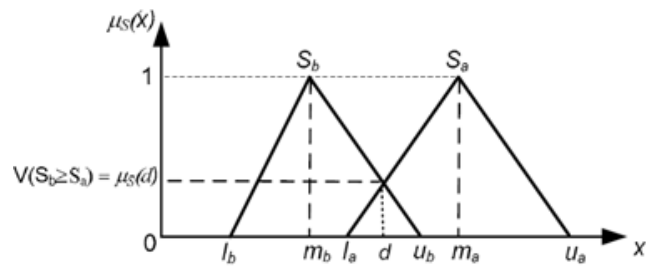

Figure 1. Intersection between $\mathrm{Sa}$ and $\mathrm{Sb}$ 
To compare $\mathrm{S} 1$ and $\mathrm{S} 2$, both values $\mathrm{V}(\mathrm{S} 1$ $\geq \mathrm{S} 2)$ i $\mathrm{V}(\mathrm{S} 2 \geq \mathrm{S} 1)$ are needed.

Step 3: Level of possibility for convex fuzzy number to be greater than , $\mathrm{K}^{\text {“ }}$ convex number $\mathrm{Si}(\mathrm{i}=1,2, \ldots, \mathrm{k})$ can be defined as follows:

$V\left(S_{i} \geq S_{1}, S_{2}, \ldots, S_{k}\right)=\min V\left(S_{i} \geq S_{k}\right),=w^{\prime}\left(S_{i}\right)$

$d^{\prime}\left(A_{i}\right)=\min V\left(S_{i} \geq S_{k}\right), k \neq i, k=1,2, \ldots, n$

The weight vector is given by the following expression:

$W^{\prime}=\left(\mathrm{d}^{\prime}\left(A_{1}\right), \mathrm{d}^{\prime}\left(A_{2}\right), \ldots, \mathrm{d}^{\prime}\left(A_{n}\right)\right)^{T}$,

Step 4: Through normalization, the weight vector is reduced to the phrase:

$W=\left(\mathrm{d}\left(A_{1}\right), \mathrm{d}\left(A_{2}\right), \ldots, \mathrm{d}\left(A_{n}\right)\right)^{T}$,

where $\mathrm{W}$ does not represent fuzzy number.

There is a significant number of publications dealing exactly with comparison of conventional AHP and fuzzy AHP, such as (Davoudi \& Sheykhvand, 2007; Özdağoğlu \& Özdağoğlu, 2007; Zhang, 2010; Kabir \& Hasin 2011; Nooramin et al., 2012; Aggarwal \& Singh, 2013).

\subsection{TOPSIS method}

The Technique for Order Preference by Similarity to Ideal Solution (TOPSIS) was first proposed by (Hwang \& Yoon, 1981). The basic idea for this method is to choose the alternative, which is as close to the positive ideal solution as possible and as far from the negative ideal solution as possible. The positive ideal solution is a solution with maximized benefit criteria and minimized cost criteria. The negative ideal solution is a solution, where the cost criteria are maximized and benefit criteria are minimized.

The following are the steps of the algorithm for solving the multi-criteria tasks of TOPSIS method:

Initial matrix:

$X=\left\|x_{i j}\right\|_{m x n}$

Step 1: Normalization of the initial matrix:

$\|X\| \rightarrow\|R\|$

$R=\left\|r_{i j}\right\|_{m x n}$

$R_{i j}=\frac{x_{i j}}{\sqrt{\sum_{i=1}^{m} x_{i j}^{2}}}$

Step 2: Weighting of the normalized matrix:

$\|R\| \rightarrow\|V\|$

$V=\left\|v_{i j}\right\|=\left\|W_{j}^{\prime} \cdot r_{i j}\right\|$

Step 3: Forming the positive ideal and negative ideal solution:

$\mathrm{A}^{+}$- the positive ideal solution, which has all best features regarding all criteria:

$$
\begin{aligned}
& A^{+}=\left\{\left(\max _{i} v_{i j} \mid j \in K^{\prime}\right) i\left(\min _{i} v_{i j} \mid j \in K^{\prime \prime}\right)\right\}= \\
& \left\{v_{1}^{+}, v_{2}^{+}, \ldots, v_{j}^{+}, \ldots, v_{n}^{+}\right\}, \quad i=\overline{1, m}
\end{aligned}
$$

$K^{\prime} \subseteq K \rightarrow K^{\prime} \quad$ is a subset of $\mathrm{K}$ consisting of max type criteria.

$K^{\prime \prime} \subseteq K \rightarrow K^{\prime \prime} \quad$ is a subset of $\mathrm{K}$ consisting of min type criteria.

$\mathrm{A}^{-}$- the negative ideal solution, which has all worst features regarding all criteria: 


$$
\begin{aligned}
& A^{-}=\left\{\left(\min _{i} v_{i j} \mid j \in K^{\prime}\right) i\left(\max _{i} v_{i j} \mid j \in K^{\prime \prime}\right)\right\}= \\
& \left\{v_{1}^{-}, v_{2}^{-}, \ldots, v_{j}^{-}, \ldots, v_{n}^{-}\right\}, \quad(i=\overline{1, m})
\end{aligned}
$$

Step 4: Calculating the distance (Euclidean distance) of each alternative from the positive ideal and negative ideal solution:

$\mathrm{S}_{1}{ }^{+}$- distance of an alternative from the positive ideal solution

$S_{i}^{+}=\sqrt{\sum_{j=1}^{n}\left(v_{i j}-v_{j}^{+}\right)^{2}}$

$\mathrm{S}_{1}^{-}$- distance of an alternative from the negative ideal solution

$S_{i}^{-}=\sqrt{\sum_{j=1}^{n}\left(v_{i j}-v_{j}^{-}\right)^{2}}$

Step 5: Calculating the relative closeness of an alternative to the ideal solution:

$C_{i}=\frac{S_{i}^{-}}{S_{i}^{-}+S_{i}^{+}}$

$0 \leq C_{i} \leq 1$

Step 6: Ranking of alternatives:

Ranking of $\mathrm{Ci}$ values arranged in descending order (from the highest to lowest value) corresponds to the ranking of $\mathrm{Ai}$ alternatives (from the best to worst).

\subsection{Input parameters in model}

Literature and various publications dealing with these or issues similar to ones from this paper, there can be found great number of criteria for supplier evaluation. However, one question arises: how to make right selection from certain group, which will assist in finding the best solution. Some authors (Weber et al. 1991) tried to answer this question at the end of last century, so they examined criteria for selection of supplier in production and retail trade surrounding. Criteria's were given in 74 documents published between 1966 and 1991. Group of authors came to conclusion that following criteria are dominant: quality, delivery and price; while geographic location, financial status and production capacities belong to secondary group of factors. Then, (Verma \& Pullman, 1998) commenced examination among big number of managers with the aim to examine in which way to make compromise during supplier selection. Their research pointed out that managers are paying the most attention to the quality as the most important suppliers's attribute, before delivery and price. Research about influence of criteria in the supply chain is continuing on during the beginning of this century as well, so (Karpak et al., 2001) took reliability of delivery as a criteria for choice making while (Bhutta \& Huq, 2002) used four criteria for evaluation of suppliers: price, quality, techniology and service.

Criteria applied in this study are: price of materials, pipe length, delivery time, way of payment, mode of delivery and quality hat are still in operation are marked with $\mathrm{C} 1-\mathrm{C} 6$ respectively. Therefore, there are three criteria, quantitatively expressed and three criteria which are qualitative, as shown in Figure 2.

Prices of materials, pipe length, delivery time and transportation distance are the quantitative criteria that are easily expressed as they represent stabil measures, ie. specific values.

Price of materials indicates the money value of goods established by the supplier based on investment in the form of materials, energy, labor, etc.

Pipe length is a parameter that is expressed in meters and which in this case 


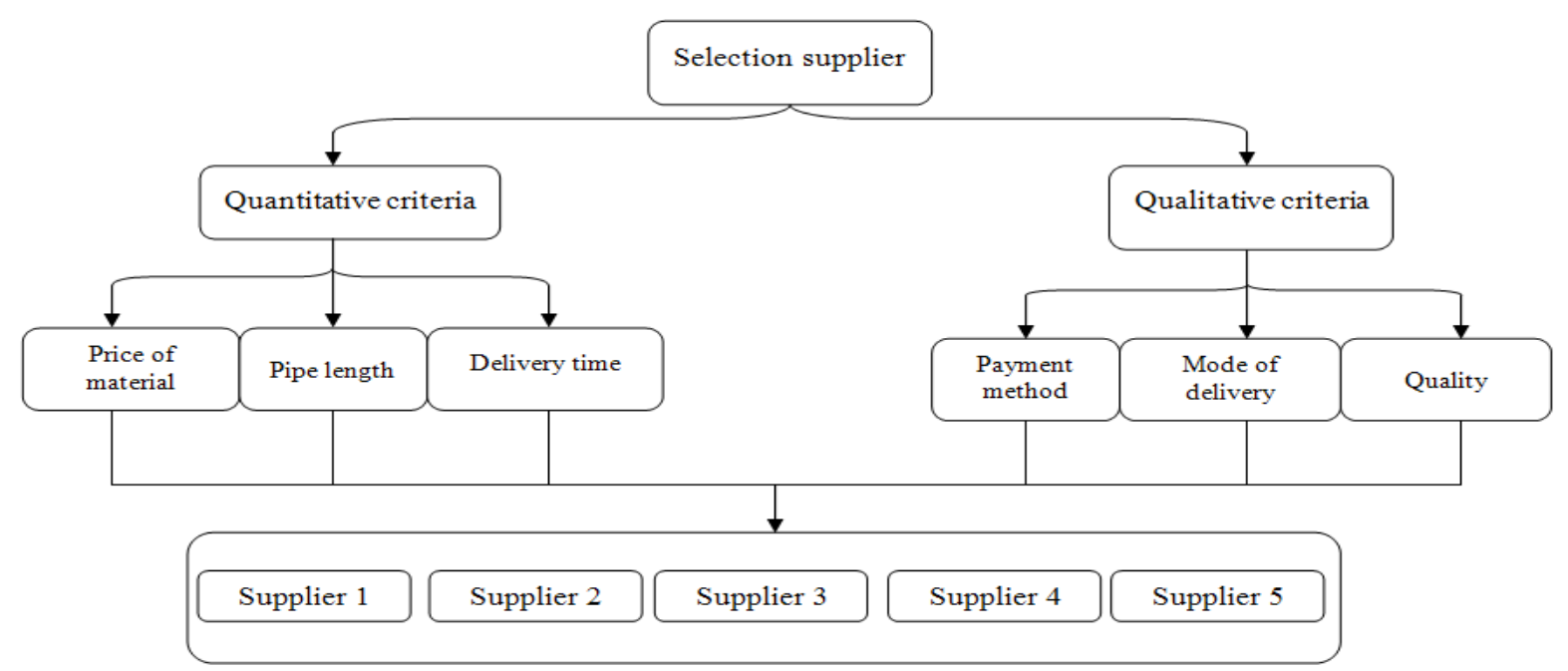

Figure 2. The hierarchical structure of the model

plays an important role due to the fact that customers often require delivery of preinsulated pipes with precisely defined length, which allows easier use.

Delivery time is the time interval between the moment of getting the order and the time of availability of goods to the customer. It is most commonly expressed in days, but can be in other time units as well.
In contrast to the above, the remaining criteria are qualitative, they represent soft masurers and are not so easy to express, so they should be presented by a descriptive mark.

Payment represent compensation in money for delivered goods as determined between the contract parties. During research, it was established that payment can

Table 1. Comparison criteria by three experts

\begin{tabular}{cccccccc}
\hline & & $\mathrm{C}_{1}$ & $\mathrm{C}_{2}$ & $\mathrm{C}_{3}$ & $\mathrm{C}_{4}$ & $\mathrm{C}_{5}$ & $\mathrm{C}_{6}$ \\
\hline $\mathrm{C}_{1}$ & $\mathrm{E}_{1}$ & $(1,1,1)$ & $(2 / 3,1,2)$ & $(1 / 2,2 / 3,1)$ & $(1 / 2,1,3 / 2)$ & $(1 / 2,1,3 / 2)$ & $(2 / 3,1,2)$ \\
& $\mathrm{E}_{2}$ & $(1,1,1)$ & $(2 / 3,1,2)$ & $(2 / 3,1,2)$ & $(1,3 / 2,2)$ & $(1 / 2,1,3 / 2)$ & $(2 / 3,1,2)$ \\
& $\mathrm{E}_{3}$ & $(1,1,1)$ & $(1 / 2,2 / 3,1)$ & $(2 / 5,1 / 2,2 / 3)$ & $(1 / 2,1,3 / 2)$ & $(1 / 2,1,3 / 2)$ & $(2 / 7,1 / 3,2 / 5)$ \\
$\mathrm{C}_{2}$ & $\mathrm{E}_{1}$ & $(1 / 2,1,3 / 2)$ & $(1,1,1)$ & $(2 / 3,1,2)$ & $(1,3 / 2,2)$ & $(1,3 / 2,2)$ & $(1,1,1)$ \\
& $\mathrm{E}_{2}$ & $(1 / 2,1,3 / 2)$ & $(1,1,1)$ & $(1,1,1)$ & $(3 / 2,2,5 / 2)$ & $(1,3 / 2,2)$ & $(1,1,1)$ \\
& $\mathrm{E}_{3}$ & $(1,3 / 2,2)$ & $(1,1,1)$ & $(2 / 3,1,2)$ & $(3 / 2,2,5 / 2)$ & $(3 / 2,2,5 / 2)$ & $(2 / 5,1 / 2,2 / 3)$ \\
$\mathrm{C}_{3}$ & $\mathrm{E}_{1}$ & $(1,3 / 2,2)$ & $(1 / 2,1,3 / 2)$ & $(1,1,1)$ & $(3 / 2,2,5 / 2)$ & $(3 / 2,2,5 / 2)$ & $(1 / 2,1,3 / 2)$ \\
& $\mathrm{E}_{2}$ & $(1 / 2,1,3 / 2)$ & $(1,1,1)$ & $(1,1,1)$ & $(3 / 2,2,5 / 2)$ & $(1,3 / 2,2)$ & $(1,1,1)$ \\
& $\mathrm{E}_{3}$ & $(3 / 2,2,5 / 2)$ & $(1 / 2,1,3 / 2)$ & $(1,1,1)$ & $(2,5 / 2,3)$ & $(2,5 / 2,3)$ & $(1 / 2,2 / 3,1)$ \\
$\mathrm{C}_{4}$ & $\mathrm{E}_{1}$ & $(2 / 3,1,2)$ & $(1 / 2,2 / 3,1)$ & $(2 / 5,1 / 2,2 / 3)$ & $(1,1,1)$ & $(1,1,1)$ & $(2 / 3,1,2)$ \\
& $\mathrm{E}_{2}$ & $(1 / 2,2 / 3,1)$ & $(2 / 5,1 / 2,2 / 3)$ & $(2 / 5,1 / 2,2 / 3)$ & $(1,1,1)$ & $(1 / 2,1,3 / 2)$ & $(2 / 5,1 / 2,2 / 3)$ \\
& $\mathrm{E}_{3}$ & $(2 / 3,1,2)$ & $(2 / 5,1 / 2,2 / 3)$ & $(1 / 3,2 / 5,1 / 2)$ & $(1,1,1)$ & $(1,1,1)$ & $(2 / 7,1 / 3,2 / 5)$ \\
$\mathrm{C}_{5}$ & $\mathrm{E}_{1}$ & $(2 / 3,1,2)$ & $(1 / 2,2 / 3,1)$ & $(2 / 5,1 / 2,2 / 3)$ & $(1,1,1)$ & $(1,1,1)$ & $(1 / 2,2 / 3,1)$ \\
& $\mathrm{E}_{2}$ & $(2 / 3,1,2)$ & $(1 / 2,2 / 3,1)$ & $(1 / 2,2 / 3,1)$ & $(2 / 3,1,2)$ & $(1,1,1)$ & $(1 / 2,2 / 3,1)$ \\
& $\mathrm{E}_{3}$ & $(2 / 3,1,2)$ & $(2 / 5,1 / 2,2 / 3)$ & $(1 / 3,2 / 5,1 / 2)$ & $(1,1,1)$ & $(1,1,1)$ & $(2 / 7,1 / 3,2 / 5)$ \\
$\mathrm{C}_{6}$ & $\mathrm{E}_{1}$ & $(1 / 2,1,3 / 2)$ & $(1,1,1)$ & $(2 / 3,1,2)$ & $(1 / 2,1,3 / 2)$ & $(1,3 / 2,2)$ & $(1,1,1)$ \\
& $\mathrm{E}_{2}$ & $(1 / 2,1,3 / 2)$ & $(1,1,1)$ & $(1,1,1)$ & $(3 / 2,2,5 / 2)$ & $(1,3 / 2,2)$ & $(1,1,1)$ \\
& $\mathrm{E}_{3}$ & $(5 / 2,3,7 / 2)$ & $(3 / 2,2,5 / 2)$ & $(1,3 / 2,2)$ & $(5 / 2,3,7 / 2)$ & $(5 / 2,3,7 / 2)$ & $(1,1,1)$ \\
\hline
\end{tabular}


be done as advance, postponed with bank guarantee, or percentage of total amount as advance, and the rest is paid postponed, what can be shown in following way: bad, acceptable, good and excellent.

Way of delivery represents a qualitative criteria that can be expressed as good, average and bad, depending of the fact whether the transport is calculated in the price of material - is it free of charge, or delivery of goods is to be done by vehicles of examined company. If it is the second option distances of suppliers must be taken into consideration, as well as expences caused by that.

The quality of materials is the level of fulfilling the requirements of regulations and standards, on the one hand and the level of fulfilling customer's expectations on the other side. It can be described as good, very good, excellent and outstanding.

Upon criteria establishing, the expert team comprised of three members compared them on the base of triangular fuzzy scale (Chang, 1996) which is shown in Table 1.

\section{RESULTS AND DISCUSSION}

Fuzzy important weight of the criteria is calculated by taking geometric mean of the responses of the experts (Lee, 2009), this is shown in Table 2. Example calcuation of geometric mean for $\mathrm{C} 12$ is:

$$
\begin{aligned}
& \mathrm{n}^{-}=(2 / 3 \times 2 / 3 \times 1 / 2)^{1 / 3}=0,606 \\
& \mathrm{n}=(1 \times 1 \times 2 / 3)^{1 / 3}=0,874 \\
& n^{+}=(2 \times 2 \times 1)^{1 / 3}=1,587
\end{aligned}
$$

To determine Fuzzy combination expansion for each one of the criteria, first we calculate $\sum_{j=1}^{n} M_{g i}^{j}$ value for each row of the matrix.

$\mathrm{C} 1=(1+0.606+0.511+0.630+0.5+0.503$; $1+0.874+0.693+1.145+1+0.694$; $1+1.587+1.817+1.651+1.5+1.17)=(3.75$; $5.406 ; 8.725$ ) etc.

The $\sum_{i=1}^{n} \sum_{j=1}^{n} M_{g i}^{j}$ value is calculated as:

$(3.75 ; 5.406 ; 8.725)+(5.585 ; 7.407 ; 9.576)$ $+(6.262 ; 8.427 ; 10.535)+(3.631 ; 4.348$; $5.912)+(3.825 ; 4.646 ; 6.564)+(6.464 ; 8.554$; $10.703)=(29.517 ; 38.788 ; 52.015)$

$$
\text { Then, } S_{i}=\sum_{j=1}^{n} M_{g i}^{j} \times\left[\sum_{i=1}^{n} \sum_{j=1}^{m} M_{g i}^{j}\right]^{-1}
$$$$
\mathrm{S} 1=(3.75 ; 5.406 ; 8.725) \times(1 / 52.015 \text {; }
$$
$1 / 38.788 ; 1 / 29.517)=(0.072 ; 0.139 ; 0.296)$ etc.

Now, the $\mathrm{V}$ values (preference order) are calculated using these vectors.

$$
V\left(S_{1} \geq S_{2}\right)=\frac{0.107-0.296}{(0.139-0.296)-(0.191-0.107)}=0.784
$$

Table 2. Fuzzy important weight of the criteria calculated by taking geometric mean

\begin{tabular}{ccccccc}
\hline & $\mathrm{C}_{1}$ & $\mathrm{C}_{2}$ & $\mathrm{C}_{3}$ & $\mathrm{C}_{4}$ & $\mathrm{C}_{5}$ & $\mathrm{C}_{6}$ \\
\hline $\mathrm{C}_{1}$ & $(1,1,1)$ & $(0.606,0.874$, & $(0.511,0.693$, & $(0.630,1.145$, & $(0.5,1,1.5)$ & $(0.503,0.694$, \\
& $1.587)$ & $1.817)$ & $1.651)$ & $1.170)$ \\
$\mathrm{C}_{2}$ & $(0.630,1.145$ & $(1,1,1)$ & $(0.763,1,1.587)$ & $(1.310,1.817$, & $(1.145,1.651$, & $(0.737,0.794$, \\
& $1.651)$ & & $2.31)$ & $2.154)$ & $0.874)$ \\
$\mathrm{C}_{3}$ & $(0.909,1.442$, & $(0.630,1,1.31)$ & $(1,1,1)$ & $(1.651,2.154$, & $(1.442,1.957$, & $(0.630,0.874$, \\
& $1.957)$ & $2.657)$ & $2.466)$ & $1.145)$ \\
$\mathrm{C}_{4}$ & $(0.606,0.784$, & $(0.431,0.550$, & $(0.376,0.464$, & $(1,1,1)$ & $(0.794,1$, & $(0.424,0.550$, \\
& $1.587)$ & $0.763)$ & $0.606)$ & & $1.145)$ & $0.811)$ \\
$\mathrm{C}_{5}$ & $(0.667,1,2)$ & $(0.464,0.606$, & $(0.405,0.511$, & $(0.874,1,1.26)$ & $(1,1,1)$ & $(0.415,0.529$, \\
& $0.874)$ & $0.693)$ & $0.737)$ \\
$\mathrm{C}_{6}$ & $(0.855,1.442$, & $(1.145,1.260$, & $(0.874,1.145$, & $(1.233,1.817$, & $(1.357,1.890$, & $(1,1,1)$ \\
\hline
\end{tabular}


$V\left(S_{1} \geq S_{3}\right)=\frac{0.12-0.296}{-0.157-0.097}=0.693$

$V\left(S_{1} \geq S_{4}\right)=1$

$V\left(S_{1} \geq S_{5}\right)=1$

$V\left(S_{1} \geq S_{6}\right)=\frac{0.124-0.296}{-0.157-0.097}=0.677$

The priorities of weights are calculated using:

$\mathrm{d}^{\prime}=(\mathrm{C} 1) \min (0.784 ; 0.693 ; 1 ; 1 ; 0.677)=0.677$

$\mathrm{d}^{\prime}=(\mathrm{C} 2) \min (1 ; 0.887 ; 1 ; 1 ; 0.870)=0.870$

$\mathrm{d}^{\prime}=(\mathrm{C} 3) \min (1 ; 1 ; 1 ; 1 ; 0.983)=0.983$

$\mathrm{d}^{\prime}=(\mathrm{C} 4) \min (0.826 ; \quad 0.541 ; 0.432 ; 0.941$;

$0.411)=0.411$

$\mathrm{d}^{\prime}=(\mathrm{C} 5) \min (0.888 ; 0.618 ; 0.513 ; 1 ; 0.492)=$ 0.492

$\mathrm{d}^{\prime}=(\mathrm{C} 6) \min (1 ; 1 ; 1 ; 1 ; 1 ; 1)=1$

After the equation is applied (10), weight values are obtained, and from the equation (11) normalized weights of criteria are received:

$\mathrm{W}^{\prime}=(0.677 ; 0.870 ; 0.983 ; 0.411 ; 0.492 ; 1)$

$\mathrm{W}=(0.15 ; 0.20 ; 0.22 ; 0.09 ; 0.11 ; 0.23)$

After determination of criteria, it is clear that the third and the sixth criteria are almost equally relevant, ie. for the company which is subject of research, delivery time and material quality represents the most important criteria during the evaluation of potential suppliers. By applying previously described steps of Topsis method, results represented by the following figure were obtained.

On figure 3 , it is visible that the alternative, ie. supplier no. 2 has the highest value and represent the best solution according to previously conducted steps. Remaining alternatives, without alternative no. 5 which is the poorest solution, could as well in certain circumstances compete for primary supplier. Depending on market

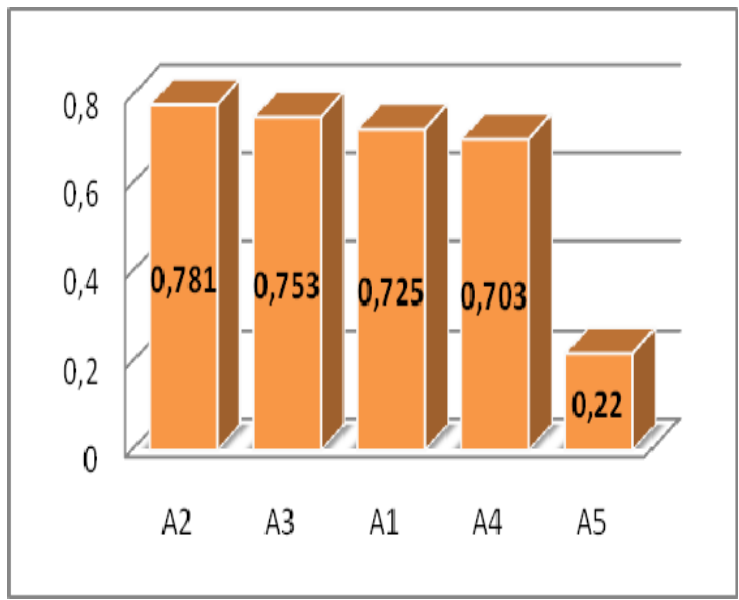

Figure 3. Ranking of alternatives

demands, changes of criteria importance, as well as company's needs, current rank of alternatives could change, even in near future; what requires constant monitoring of own performanses and performanses of potential suppliers.

\section{CONCLUSION}

Estimation of supplier's value for companies dealing with production, especially ones without big storage area for material stocks necessary for production proccess represents a key strategic issue. In order to make possible timely, high-quality and favorable production, it is necessary to look into market from diferent aspects. Among most important ones is the aspect of end user, ie. demands the end user have while making decision about product purchasing.

Logistic of purchasing nowadays plays very important role in the supply chain, its optimization enables company to achieve significant efect on entire logistics system. When it comes to purchasing the requred materials, it is necessary to take care of great amount of criteria with potential influence on 
forming the final product's price, as well as on position in the market obtained by company. Therefore, evaluation of suppliers using the combination of multi-criteria methods, can bring clearer picture about all potential suppliers, their advantages and weaknesses.

In its work, expert team which is integral part of the company where the research was done, based on previously described methodology, chose five suppliers which are compeeting for the job of securing the purchase system, out of wich supplier no. 5 can for sure be excluded from combination because it represents far weaker solution in comparison with other suppliers.

Effective flow of materials requires efficient operating, where applying of these methods can be of significant help.

\title{
ИНТЕГРИСАНИ “FUZZY АНР" И “ТОРSIS" МОДЕЛ ЗА ВРЕДНОВАЊЕ ДОБАВЉАЧА
}

\author{
Жељко Стевић, Илија Танацков, Марко Васиљевић, Борис Новарлић \\ и Гордан Стојић
}

\begin{abstract}
Извод
У данашњим савременим ланцима снабдевања адекватан избор добављача представља питање од стратешког значаја за целокупно пословање компанија. Циљ рада је извршити вредновање добављача применом интегрисаног модела који подразумева комбинацију fuzzy AHP (аналитичко хијерархијски процес) и TOPSIS методе. На основу шест критеријума експертски тим који је формиран врши поређење критеријума, те се одређивање њиховог значаја врши примењујући fuzzy AHР методу. Поређење добављача према сваком критеријуму на основу троугаоних fuzzy бројева такође извршава експертски тим и на основу њихових улазних података приступа се вредновању потенцијалних решења применом TOPSIS методе. Предложеним моделом остварују се одређене предности у односу на претходне традиционалне моделе на бази којих су се доносиле одлуке о вредновању и избору добављача.
\end{abstract}

Кључне речи: Fuzzy AHP, TOPSIS, вредновање добављача, вишекритеријумско одлучивање

\section{References}

Aggarwal, R., \& Singh, S. (2013). AHP and Extent Fuzzy AHP Approach for Prioritization of Performance Measurement Attributes. World Academy of Science, Engineering and Technology, 73, 145-151.

Anagnostopoulos, K.P., Gratziou, M., \& Vavatsikos, A.P. (2007). Using the fuzzy analytic hierarchy process for selecting wastewater facilities at prefecture level. European Water, 19 (20), 15-24.

Ayhan, M.B. (2013). A Fuzzy AHP approach for supplier selection problem: a case study in a gear motor company. International Journal of Managing Value and Supply Chains 4 (3), (2013), 11-23.

Ballı, S., \& Korukoğlu, S. (2009). 
Operating system selection using fuzzy AHP and TOPSIS methods. Mathematical and Computational Applications, 14 (2), 119130.

Barbarosoglu, G., \& Yazgac, T. (1997). An application of the analytic hierarchy process to the supplier selection problem. Production and Inventory Management Journal, 38 (1), 14-21.

Benyoucef, M., \& Canbolat, M. (2007). Fuzzy AHP-based supplier selection in eprocurement. International Journal of Services and Operations Management, 3 (2), 172-192.

Bhutta, K.S., \& Huq, F. (2002). Supplier selection problem: a comparison of the total cost of ownership and analytic hierarchy process approaches. Supply Chain Management: An International Journal, 7 (3), 126-135.

Bronja, H., \& Bronja, H. (2015). Twophase selection procedure of aluminized sheet supplier by applying fuzzy AHP and fuzzy TOPSIS methodology. Tehnički vjesnik, 22 (4), 821-828.

Chan, F.T., \& Kumar, N. (2007). Global supplier development considering risk factors using fuzzy extended AHP-based approach. Omega, 35 (4), 417-431.

Chang, D.Y. (1996). Applications of the extent analysis method on fuzzy AHP. European Journal of Operational Research, 95 (3), 649-655.

Chen, C.T., Lin, C.T., \& Huang, S.F. (2006). A fuzzy approach for supplier evaluation and selection in supply chain management. International journal of production economics, 102 (2), 289-301.

Davoudi, M.R., \& Sheykhvand, K. (2007). Enterprise Architecture Analysis Using AHP and Fuzzy AHP. In Proceedings of 2011 4th IEEE International Conference on Computer Science and Information
Technology (ICCSIT 2011). VOL07, 202207.

Ertugrul, I., \& Karakasoglu, N. (2006). The fuzzy analytic hierarchy process for supplier selection and an application in a textile company. Proceedings of 5th international symposium on intelligent manufacturing systems, 195-207.

Fazlollahtabar, H., Eslami, H., \& Salmani, H. (2010). Designing a fuzzy expert system to evaluate alternatives in fuzzy analytic hierarchy process. Journal of Software Engineering and Applications, 3 (4), 409418.

Haq, A.N., \& Kannan, G. (2006). Fuzzy analytical hierarchy process for evaluating and selecting a vendor in a supply chain model. The International Journal of Advanced Manufacturing Technology, 29 (78), 826-835.

Ho, W., Xu, X., \& Dey, P.K. (2010). Multi-criteria decision making approaches for supplier evaluation and selection: A literature review. European Journal of Operational Research, 202 (1), 16-24.

Hwang, C.L., \& Yoon, K. (1981). Multiple attributes decision making methods and applications. Berlin: Springer.

Kabir, G., \& Hasin, M.A.A. (2011). Comparative analysis of AHP and Fuzzy AHP models for multicriteria inventory classification. International Journal of Fuzzy Logic Systems, 1 (1), 1-16.

Kahraman, C., Cebeci, U., \& Ruan, D. (2004). Multi-attribute comparison of catering service companies using fuzzy AHP: The case of Turkey. International Journal of Production Economics, 87 (2), 171-184.

Kahraman, C., Cebeci, U., \& Ulukan, Z. (2003). Multi-criteria supplier selection using fuzzy AHP. Logistics Information Management, 16 (6), 382-394. 
Karpak, B., Kumcu, E., \& Kasuganti, R.R. (2001). Purchasing materials in the supply chain: managing a multi-objective task. European Journal of Purchasing \& Supply Management, 7 (3), 209-216.

Kilincci, O., \& Onal, S.A. (2011). Fuzzy AHP approach for supplier selection in a washing machine company. Expert systems with Applications, 38 (8), 9656-9664.

Lee, A.H. (2009). A fuzzy supplier selection model with the consideration of benefits, opportunities, costs and risks. Expert systems with applications, 36 (2), 2879-2893.

Lee, A.H., Chen, W.C., \& Chang, C.J. (2008). A fuzzy AHP and BSC approach for evaluating performance of IT department in the manufacturing industry in Taiwan. Expert systems with applications, 34 (1), 96107.

Mahmoodzadeh, S., Shahrabi, J., Pariazar, M., \& Zaeri, M.S. (2007). Project selection by using fuzzy AHP and TOPSIS technique. International Journal of Human and social sciences, 1 (3), 135-140.

Mikhailov, L. (2003). Deriving priorities from fuzzy pairwise comparison judgements. Fuzzy sets and systems, 134 (3), 365-385.

Nooramin, A.S., Kiani Moghadam, M., Moazen Jahromi, A.R., \& Sayareh, J. (2012). Comparison of AHP and FAHP for selecting yard gantry cranes in marine container terminals. Journal of the Persian Gulf, 3 (7), 59-70.

Nydick, R.L., \& Hill, R.P. (1992). TJsing the Analytic Hierarchy Process to Structure the Supplier Selection Procedure.

Özdağoğlu, A., \& Özdağoğlu, G. (2007). Comparison of AHP and fuzzy AHP for the multi-criteria decision making processes with linguistic evaluations. İstanbul Ticaret Üniversitesi Fen Bilimleri Dergisi, 6 (11), 65-85.
Raja Prasad, S.V.S., \& Chalapathi Venkata, P. (2013). Evaluation of Impact of Safety Training Programme in Indian Construction Industry - Analytic Hierarchy Process Approach. International Journal of Engineering, Business and Enterprise Applications, 7 (1), 49-54.

Saaty, T.L. (1980). The Analytic Hierarchy Process, Mc Graw-Hill, New York.

Saaty, T.L. (1986). Axiomatic foundation of the analytic hierarchy process. Management science, 32 (7), 841-855.

Saaty, T.L. (1988). What is the analytic hierarchy process? Springer Berlin Heidelberg, 109-121.

Saaty, T.L. (1990). How to make a decision: the analytic hierarchy process. European journal of operational research, 48 (1), 9-26.

Saaty, T.L. (2003). Decision-making with the AHP: Why is the principal eigenvector necessary. European journal of operational research, 145 (1), 85-91.

Saaty, T.L. (2008). Decision making with the analytic hierarchy process. International Journal of Services Sciences, 1 (1), 83-98.

Saaty, T.L., \& Vargas, L.G. (2012). Models, Methods, Concepts \& Applications of the Analytic Hierarchy Process, Second Edition. Springer Science \& Business Media, New York.

Shukla, R.K., Garg, D., \& Agarwal, A. (2014). An integrated approach of Fuzzy AHP and Fuzzy TOPSIS in modeling supply chain coordination. Production \& Manufacturing Research, 2 (1), 415-437.

Srichetta, P., \& Thurachon, W. (2012). Applying Fuzzy Analytic Hierarchy Process to Evaluate and Select Product of Notebook Computers. International Journal of Modelling and Optimization, 2 (2), 168-173. Stević, Ž., Vesković, S., Vasiljević, M., \& 
Tepić, G. (2015a). The selection of the Transactions on Fuzzy Systems, 22 (4), 749logistics center location using AHP method. 761.

University of Belgrade, Faculty of Transport and Traffic Engineering, LOGIC, Belgrade, 86-91.

Stević, Ž., Božičković, Z., \& Mićić, B. (2015b). Optimization of the import of Chipboard - a case study. International Journal of Engineering, Business and Enterprise Applications, 14 (1), 19-23.

Stević, Ž., Alihodžić, A., Božičković, Z., Vasiljević, M., \& Vasiljević, Đ. (2015c). Application of combined AHP-TOPSIS model for decision making in management. 5th International conference „Economics and Management -based On New Technologies“ EMONT /Vrnjačka Banja, Serbia, 33-40.

Sun, C.C. (2010). A performance evaluation model by integrating fuzzy AHP and fuzzy TOPSIS methods. Expert systems with applications, 37 (12), 7745-7754.

Vaidya, O.S., \& Kumar, S. (2006). Analytic hierarchy process: An overview of applications. European Journal of operational research, 169 (1), 1-29.

Verma, R., \& Pullman, M.E. (1998). An analysis of the supplier selection process. Omega, 26 (6), 739-750.

Wang, Y.M., \& Chin, K.S. (2011). Fuzzy analytic hierarchy process: A logarithmic fuzzy preference programming methodology. International Journal of Approximate Reasoning, 52 (4), 541-553.

Wang, Y.M., Luo, Y., \& Hua, Z. (2008). On the extent analysis method for fuzzy AHP and its applications. European Journal of Operational Research, 186 (2), 735-747.

Weber, C.A., Current, J. R., \& Benton, W.C. (1991). Vendor selection criteria and methods. European Journal of Operational Research, 50 (1), 2-18.

Xu, Z., \& Liao, H. (2014). Intuitionistic fuzzy analytic hierarchy process. IEEE
Zadeh, L.A. (1965). Fuzzy sets. Information and Control, 8 (3), 338-353.

Zeydan, M., Çolpan, C., \& Çobanoğlu, C. (2011). A combined methodology for supplier selection and performance evaluation. Expert Systems with Applications, 38 (3), 2741-2751.

Zhang, L. (2010). Comparison of classical analytic hierarchy process (AHP) approach and fuzzy AHP approach in multiple-criteria decision making for commercial vehicle information systems and networks (CVISN) project.

Zhu, K.J., Jing, Y., \& Chang, D.Y. (1999). A discussion on extent analysis method and applications of fuzzy AHP. European Journal of Operational Research, 116 (2), 450-456. 